\title{
Hepatic Tissue
}

National Cancer Institute

\section{Source}

National Cancer Institute. Hepatic Tissue. NCI Thesaurus. Code C32735.

The tissue of the liver. It includes the hepatic lobules, hepatic sinusoids, perisinusoidal spaces, and portal triad. The hepatic lobules are composed of hepatocytes. 